\title{
Serum Neurofilament Levels and PML Risk in Patients With Multiple Sclerosis Treated With Natalizumab
}

Nicolás Fissolo, PhD, Beatrice Pignolet, PhD, Jordi Rio, MD, PhD, Patrick Vermersch, MD, PhD, Aurélie Ruet, MD, PhD, Jerome deSèze, MD, PhD, Pierre Labauge, MD, PhD, Sandra Vukusic, MD, PhD, Caroline Papeix, MD, Laurent Martinez-Almoyna, MD, Ayman Tourbah, MD, PhD, Pierre Clavelou, MD, PhD, Thibault Moreau, MD, PhD, Jean Pelletier, MD, PhD, Christine Lebrun-Frenay, MD, PhD, Bertrand Bourre, MD, Gilles Defer, MD, PhD, Xavier Montalban, MD, David Brassat, MD, PhD, and Manuel Comabella, MD, PhD

Neurol Neuroimmunol Neuroinflamm 2021;8:e1003. doi:10.1212/NXI.0000000000001003

\section{Abstract}

\section{Objectives}

The study aimed to assess the potential for serum neurofilament light chain (NFL) levels to predict the risk of progressive multifocal leukoencephalopathy (PML) in natalizumab (NTZ)treated patients with multiple sclerosis (MS) and to discriminate PML from MS relapses.

\section{Methods}

NFL levels were measured with single molecule array (Simoa) in 4 cohorts: (1) a prospective cohort of patients with MS who developed PML under NTZ therapy (pre-PML) and non-PML NTZ-treated patients (NTZ-ctr); (2) a cohort of patients whose blood was collected during PML; (3) an independent cohort of non-PML NTZ-treated patients with serum NFL determinations at 2 years (replication cohort); and (4) a cohort of patients whose blood was collected during exacerbations.

\section{Results}

Serum NFL levels were significantly increased after 2 years of NTZ treatment in pre-PML patients compared with NTZ-ctr. The prognostic performance of serum NFL levels to predict PML development at 2 years was similar in the NTZ-ctr group and replication cohort. Serum NFL levels also distinguished PML from MS relapses and were 8-fold higher during PML compared with relapses.

\section{Conclusions}

These results support the use of serum NFL levels in clinical practice to identify patients with relapsing-remitting MS at higher PML risk and to differentiate PML from clinical relapses in NTZ-treated patients.

\section{Classification of Evidence}

This study provides Class I evidence that serum NFL levels can identify NTZ-treated patients with MS who will develop PML with a sensitivity of $67 \%$ and specificity of $80 \%$.
Correspondence: Dr. Fissolo nicolas.fissolo@vhir.org

\section{MORE ONLINE}

$\rightarrow$ Class of Evidence

Criteria for rating therapeutic and diagnostic studies

NPub.org/coe 


\section{Glossary}

AUC = area under the ROC curve; MS = multiple sclerosis; NFL = neurofilament light chain; NTZ = natalizumab; PML = progressive multifocal leukoencephalopathy; RRMS = relapsing-remitting multiple sclerosis.

Despite its proved efficacy for patients with highly active relapsing-remitting multiple sclerosis (RRMS), ${ }^{1}$ the use of natalizumab (NTZ) is limited due to the increased risk of progressive multifocal leukoencephalopathy (PML). ${ }^{2}$ In addition to existing PML risk stratification algorithms based on NTZ treatment duration, previous immunosuppressive therapies, and JC virus index, ${ }^{2,3}$ other biomarkers may certainly contribute to estimate the risk of PML at an individual level.

Numerous studies suggest that the concentration of neurofilament light chain (NFL) in peripheral blood and CSF is a promising biomarker in MS. ${ }^{4,5}$ In a recent study, the serum NFL levels measured with an electrochemiluminescence assay were proposed as a biomarker for early identification of PML in patients with MS under NTZ treatment. ${ }^{6}$ In the present study, we aimed to expand on the potential for serum NFL levels measured with single molecule array (Simoa) to predict the risk of PML in a prospective cohort of NTZ-treated patients. We also aimed to discriminate PML from MS relapses based on serum NFL levels.

\section{Methods}

\section{Patient Cohorts}

Four different cohorts of patients with RRMS were included in the study:

1. A multicentric prospective cohort of patients treated with NTZ (BIONAT cohort; ClinicalTrials.gov identifier: NCT00942214) ${ }^{7}$ was used to evaluate the association between serum NFL levels at baseline and at 1 and 2 years of NTZ treatment and PML development. Patients belonging to this cohort were classified into 2 groups: patients who did not develop PML after a follow-up longer than 5 years (NTZ controls; NTZ-ctr) and patients who developed PML (pre-PML) under NTZ treatment.

2. A cohort of patients whose blood was drawn during the PML condition was included for comparison of NFL levels with the pre-PML group after 2 years of treatment (during PML cohort).

3. An independent cohort of patients treated with NTZ who did not develop PML after more than 5 years of follow-up was included to assess the reproducibility between centers of serum NFL measurements after 2 years of NTZ treatment (replication cohort).

4. A cohort of patients whose blood was collected at the time of an acute relapse was included to investigate the potential for serum NFL levels to discriminate between the PML condition and MS relapses (relapsing cohort). Twentyseven percent of these patients were receiving treatment with interferon-beta at the time of exacerbations.
The table summarizes the main demographic and baseline clinical characteristics of patients included in the study.

\section{Standard Protocol Approvals, Registrations, and Patient Consents}

Written informed consent was obtained from each participant. The study was approved by the local hospital ethics committees, BIONAT cohort; ClinicalTrials.gov identifier: NCT00942214, and Vall d'Hebron Hospital (EPA(AG)57/2013(3834)).

\section{Quantification of Serum NFL Levels}

Peripheral blood was collected by standard venipuncture and allowed to clot spontaneously for 30 minutes. Serum was obtained by centrifugation and stored frozen at $-80^{\circ} \mathrm{C}$ until used. Levels of NFL were measured in serum samples using commercially available NFL immunoassay kits (Quanterix, cat\#103186) run on the fully automated ultrasensitive Simoa HD-1 Analyzer (Quanterix). Samples were run in duplicate in accordance with manufacturers' instructions with appropriate standards and internal controls. The intra-assay and interassay coefficients of variation were $5 \%$ and $9 \%$, respectively.

\section{Classification of Evidence}

Our primary research question was to ascertain whether serum NFL levels can identify NTZ-treated patients with MS who will develop PML. The classification of evidence assigned to this question is Class I.

\section{Statistical Analyses}

Statistical analysis was performed by using the IBM SPSS Statistics version 22. The distribution of serum NFL levels was tested for normality with a Kolmogorov-Smirnov test. Afterward, paired and unpaired nonparametric tests were applied for comparisons of mean NFL levels among groups. When needed, analysis was adjusted by age and disease duration. Quantitative data are presented as mean values \pm SD unless otherwise stated. Differences were considered statistically significant when $p$ values were below 0.05 . Receiver operating characteristic (ROC) curve analyses were used to determine the best cutoff values based on serum NFL levels and the respective sensitivities and specificities.

\section{Data Availability}

All data analyzed during this study will be shared anonymized by request of a qualified investigator to the corresponding author.

\section{Results}

\section{Serum NFL Levels Are Elevated After 2 Years of NTZ Treatment in Pre-PML Patients and During PML}

At baseline, no significant differences were observed in serum NFL levels between pre-PML and NTZ-ctr patients. At 1 and 
Table Demographic and Baseline Clinical Characteristics of Patients With RRMS Treated With NTZ

\begin{tabular}{|c|c|c|c|c|c|}
\hline \multirow[b]{2}{*}{ Baseline characteristics } & \multicolumn{2}{|c|}{ BIONAT cohort } & \multirow[b]{2}{*}{ During PML cohort ${ }^{\mathrm{a}}$} & \multirow{2}{*}{$\begin{array}{l}\text { Replication } \\
\text { cohort }^{\mathrm{b}}\end{array}$} & \multirow[b]{2}{*}{ Relapsing cohort $^{c}$} \\
\hline & NTZ-ctr ${ }^{d}$ & Pre-PML ${ }^{\mathrm{e}}$ & & & \\
\hline $\mathbf{n}$ & 37 & 17 & 13 & 29 & 30 \\
\hline Age (y) & $36.2(8.1)$ & $38.6(8.0)$ & $37.6(4.0)$ & $37.1(11.0)$ & $32.3(9.5)$ \\
\hline Female/male (\% women) & $29 / 8(78.4)$ & $13 / 4(76.5)$ & $10 / 3(76.9)$ & $19 / 10(65.5)$ & $23 / 7(76.7)$ \\
\hline Duration of disease $(y)$ & $9.5(6.4)$ & $11.4(6.1)$ & $11.4(6.4)$ & $9.0(6.6)$ & $7.2(6.2)$ \\
\hline EDSS score at baseline $^{f}$ & $3.0(2.0-4.2)$ & $3.7(2.6-5.4)$ & $4.2(1.6-5.4)$ & $4.0(2.5-5.2)$ & $3.0(2.4-3.6)^{g . h}$ \\
\hline JCV status (+/-/unknown) at baseline & 23/14/0 & $13 / 0 / 4$ & $4 / 0 / 9$ & $2 / 4 / 23$ & - \\
\hline Duration of NTZ treatment/time to PML $(y)^{\mathrm{i}}$ & $6.1(1.6)$ & $3.7(1.4)$ & $3.2(0.7)$ & $7.1(3.7)$ & - \\
\hline Serum NFL levels $(p g / m L)^{f}$ & $8.9(6.4-18.4)$ & $16.0(10.2-21.5)$ & $171.1(130.0-231.0)$ & $6.2(5.0-8.3)$ & $13.9(7.6-21.8)$ \\
\hline
\end{tabular}

Abbreviations: EDSS = Expanded Disability Status Scale; JCV = JC virus; NFL = neurofilament light chain; NTZ = natalizumab; PML = progressive multifocal leukoencephalopathy; RRMS = relapsing-remitting multiple sclerosis.

Data are expressed as mean (SD) unless otherwise stated.

a During PML: refers to patients whose blood was collected during the PML condition (4 patients in this group are shared with the pre-PML group). In this group, information on the time between PML onset and blood collection was not available in for 4 patients.

${ }^{b}$ Replication cohort: refers to an independent cohort of patients treated with NTZ who did not develop PML, and serum NFL levels were measured after 2 years of treatment.

'Relapsing cohort: refers to a cohort of patients with MS whose blood was collected at the time of a clinical relapse. In this group, 8 patients (26.7\%) were receiving treatment with interferon-beta during relapses, but none of the patients were treated with corticosteroids before blood extraction.

d NTZ-ctr: refers to patients with MS treated with NTZ who did not develop PML.

e pre-PML: refers to patients with MS treated with NTZ who developed PML.

${ }^{\mathrm{f}}$ Data are expressed as median (interquartile range).

g Refers to EDSS score during relapse.

${ }^{h}$ Information on EDSS score was not available in 10 patients. Duration of disease is calculated from disease onset to baseline. Age, percentage of women, duration of disease, and EDSS score at baseline did not statistically significantly differ between the NTZ-ctr group, pre-PML group, during PML cohort, and replication cohort. A trend for older age was observed in the during PML cohort compared with the relapsing cohort $(p=0.07)$. Percentage of women, duration of disease, and EDSS score were not significantly different between these 2 cohorts of patients.

i Refers to mean time of NTZ treatment in the NTZ-ctr group and replication cohort and time to conversion to PML in the pre-PML group and during PML cohort.

2 years, serum NFL levels were significantly reduced by the effect of NTZ treatment both in the pre-PML and NTZ-ctr groups (figure 1). Comparisons of serum NFL levels at 1 and 2 years between pre-PML and NTZ-ctr patients revealed higher NFL levels only in those patients with MS who will develop PML after 2 years of NTZ treatment with mean values of $10.1 \pm 5.9 \mathrm{pg} / \mathrm{mL}$ and $7.1 \pm 2.5 \mathrm{pg} / \mathrm{mL}$, respectively ( $p=0.03$ both unadjusted and after adjusting for age and disease duration; figure 1 ).

In the during PML cohort, blood was collected at a mean time from PML onset of $8.1 \pm 16.3$ days. Serum NFL levels during PML were higher compared with pre-PML patients after 2 years of NTZ treatment with mean values of $163.6 \pm 153.8 \mathrm{pg} / \mathrm{mL}$ and $10.1 \pm 5.9 \mathrm{pg} / \mathrm{mL}$, respectively (unadjusted, $p=7 \times 10^{-5}$; after adjusting for age and disease duration, $p=0.02$; figure 1 ), which represents a 16 -fold increase in serum NFL levels.

\section{Serum NFL Levels Discriminate Between Pre- PML and NTZ-ctr Patients After 2 Years of NTZ Treatment}

Figure 2A shows the prognostic performance of serum NFL levels to predict PML development at 2 years. The area under the ROC curve (AUC) was $71 \%(p=0.03)$, and a serum NFL value of $8.4 \mathrm{pg} / \mathrm{mL}$ resulted in the best cutoff to classify prePML and NTZ-ctr patients after 2 years of NTZ treatment, with a sensitivity of $67 \%$ and specificity of $80 \%$.
As shown in figure $2 \mathrm{~B}$, the distribution of serum NFL values in the replication cohort was similar to the NTZ-ctr group at 2 years of treatment, with mean NFL values of $6.9 \pm 2.5 \mathrm{pg} / \mathrm{mL}$ and $7.1 \pm 2.5 \mathrm{pg} / \mathrm{mL}$, respectively. Performance of NFL levels in the replication cohort to predict PML was comparable to the NTZ-ctr cohort at 2 years, with an AUC of $71 \%(p=0.03)$, and a serum NFL level of $8.1 \mathrm{pg} / \mathrm{ml}$ as the best cutoff to classify pre-PML patients at 2 years and patients from the replication cohort, with a sensitivity and specificity of $67 \%$ and $76 \%$, respectively (figure $2 \mathrm{C}$ ).

\section{Serum NFL Levels Distinguish PML From MS Relapses}

Serum NFL levels in the relapsing cohort did not significantly differ between untreated and interferon-beta-treated patients, and hence, this cohort was first analyzed as a whole. Comparison of serum NFL levels between PML and MS relapses revealed significantly higher NFL levels in patients during the PML condition $\left(p=3 \times 10^{-6}\right.$; figure $\left.3 \mathrm{~A}\right)$, which represents a 8-fold increase in serum NFL levels compared with the relapsing cohort (mean levels: $163.6 \pm 153.8 \mathrm{pg} / \mathrm{mL}$ vs $20.8 \pm 28.0 \mathrm{pg} / \mathrm{mL}$, respectively). Performance of serum NFL levels to differentiate between PML and MS relapses showed an AUC of 91\% ( $p=2 \times$ $10^{-5}$ ), with an NFL value of $52.7 \mathrm{pg} / \mathrm{mL}$ as the best cutoff to classify PML and MS relapses (figure 3B). Sensitivity and specificity associated with this cutoff were $85 \%$ and $93 \%$, respectively. 
Figure 1 Increased NFL Levels in Serum After 2 Years of NTZ Treatment in Pre-PML Patients Compared With NTZ-ctr

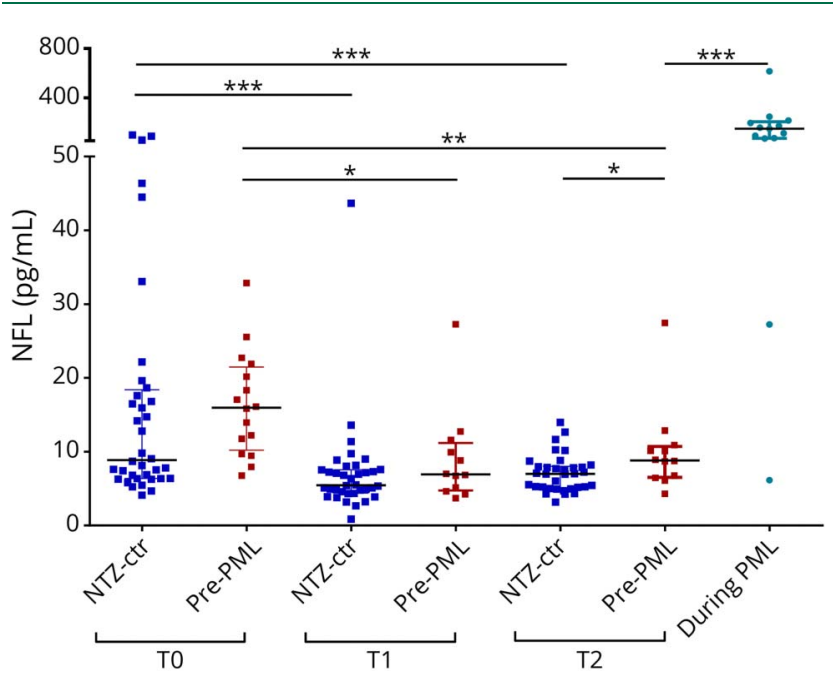

Graphs comparing serum NFL levels between pre-PML and NTZ-ctr patients at baseline (T0; $n=16$ for pre-PML and $n=36$ for NTZ-ctr), after 1 (T1; $n=12$ for pre-PML and $n=36$ for NTZ-ctr) and 2 years (T2; $n=12$ for pre-PML and $n$ = 34 for NTZ-ctr) of treatment and during PML $(n=13)$. Each symbol represents an individual, and horizontal bars indicate the median values and interquartile ranges. A y-axis segmentation was performed to represent better high and low serum NFL levels. *Refers to $p$ values $<0.05$. ** Refers to $p$ values $<0.01$. $* \star *$ Refers to $p$ values $<0.001$ in Mann-Whitney $U$ tests (unpaired data) and Wilcoxon matched-paired test (paired data). NFL = neurofilament light chain; $\mathrm{NTZ}=$ natalizumab; $\mathrm{PML}=$ progressive multifocal leukoencephalopathy.

A subanalysis in the untreated relapsing patients revealed similar results to the whole cohort, with an AUC of $90 \%(p=9$ $\times 10^{-5}$ ) and the same NFL value of $52.7 \mathrm{pg} / \mathrm{mL}$ as the best cutoff to classify patients. Sensitivity and specificity were $85 \%$ and $91 \%$, respectively.

\section{Discussion}

Few molecular biomarker studies have aimed to identify patients with $\mathrm{MS}$ at increased risk for PML under NTZ treatment. ${ }^{8-10}$ However, none of the proposed biomarkers are at present routinely measured in clinical practice to estimate PML risk in patients with RRMS receiving NTZ. In a recent study, serum NFL levels measured with an electrochemiluminescence assay were found to be 10-fold higher at PML onset compared with the pre-PML condition. ${ }^{6}$ Furthermore, serum NFL levels also demonstrated high performance to discriminate between patients with MS at PML onset and NTZ-treated patients who did not develop PML and treated patients with clinical or neuroradiologic evidence of disease activity 4 weeks before sample collection. ${ }^{6}$

In our study, serum NFL levels measured in a prospective cohort of NTZ-treated patients with the more sensitive Simoa assay ${ }^{11}$ were not predictive of PML development at baseline or after 1 year of treatment. However, despite a general significant decrease by the effect of treatment, serum NFL levels at 2 years were significantly increased in patients who will develop PML compared with NTZ-ctr patients, and NFL levels had good potential to discriminate between these 2 groups of patients in terms of PML development. Of interest, performance of serum NFL levels to predict PML in an independent cohort of NTZ-treated patients for 2 years was remarkably similar to the original cohort, results that support the use of similar cutoff values between MS centers to estimate PML risk in different cohorts of patients with MS after 2 years of NTZ treatment.

In agreement with Dalla Costa et al., ${ }^{6}$ serum NFL levels were far more elevated during PML compared with earlier stages of the disease. In our study, NFL levels were 16-fold higher during PML compared with pre-PML patients at 2 years of NTZ treatment and 8-fold higher compared with a relapsing cohort. The latter may have implications in clinical practice to set a cutoff value of serum NFL levels that distinguish the PML condition from clinical relapses in patients receiving NTZ treatment. A limitation in our study was the inclusion of a relapsing cohort either untreated or receiving interferonbeta, a treatment that was not associated with significant reductions in serum NFL levels. In this context, the inclusion of a relapsing cohort of NTZ-treated patients would probably have been associated with greater differences in serum NFL levels between relapsing and PML patients, considering the

Figure 2 Serum NFL Levels Differentiate Between Pre-PML and NTZ-ctr Patients After 2 Years of NTZ Treatment

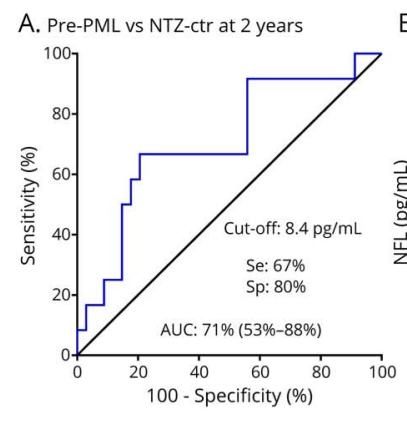

B

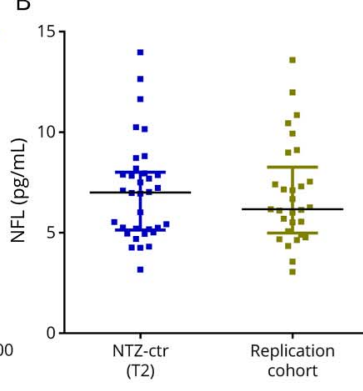

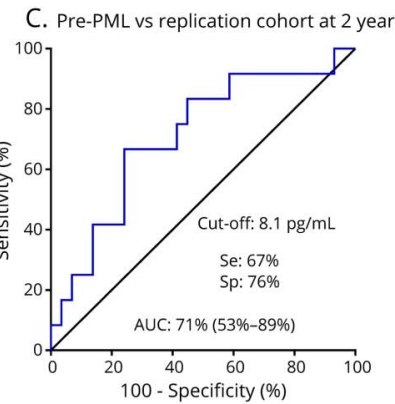

(A) Performance of serum NFL levels to discriminate between pre-PML and NTZ-ctr patients after 2 years of treatment. (B) Distribution of serum NFL levels in the NTZ-ctr cohort at 2 years of treatment $(n=34)$, and in an independent cohort of patients with MS treated with NTZ for 2 years (replication cohort; $n=29$ ). (C) Performance of the serum NFL levels to discriminate between pre-PML patients at 2 years and patients from the replication cohort after 2 years of treatment. NFL = neurofilament light chain; NTZ = natalizumab; $\mathrm{PML}=$ progressive multifocal leukoencephalopathy. 
A

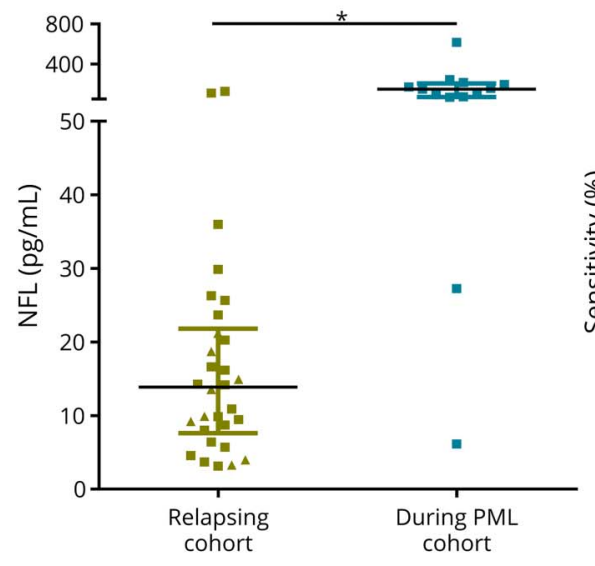

B. During PML vs relapsing cohorts

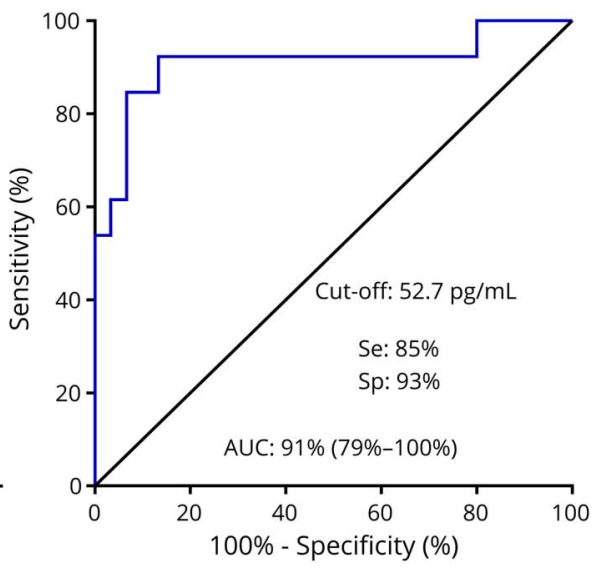

(A) Distribution of serum NFL levels in the relapsing cohort $(n=30)$ and during PML $(n=13)$. A $y$-axis segmentation was performed to represent better high and low serum NFL levels. * $p$ $=3 \times 10^{-6}$ In the relapsing cohort: untreated patients are represented in solid squares and interferon-beta-treated patients in solid triangles. (B) Performance of the serum NFL levels to discriminate between MS relapses and PML. Numbers in parentheses represent $95 \%$ Cls of the AUC. $A \cup C=$ area under the ROC curve; $M S=$ multiple sclerosis; NFL = neurofilament light chain; $\mathrm{PML}=$ progressive multifocal leukoencephalopathy; $\mathrm{Se}=$ sensitivity; $\mathrm{Sp}=$ specificity. effect of NTZ reducing significantly serum NTL levels, as shown in our study.

Based on our findings, in patients receiving NTZ treatment, we recommend to measure NFL levels longitudinally, and those patients having protein levels above the cut-offs calculated in the study after 2 years of treatment should be monitored more closely for neurologic symptoms with additional NFL and MRI measures to rule out PML.

In conclusion, our results support the use of serum NFL levels in clinical practice to identify patients with RRMS at higher risk for PML based on protein levels at 2 years of NTZ treatment and to differentiate PML from clinical relapses in patients receiving NTZ.

\section{Study Funding}

No targeted funding reported.

\section{Disclosure}

The authors report no disclosures relevant to the manuscript. Go to Neurology.org/NN for full disclosures.

\section{Publication History}

Received by Neurology: Neuroimmunology \& Neuroinflammation November 23, 2020. Accepted in final form March 3, 2021.

Appendix Authors

\begin{tabular}{|c|c|c|}
\hline Name & Location & Contribution \\
\hline $\begin{array}{l}\text { Nicolás } \\
\text { Fissolo, PhD }\end{array}$ & $\begin{array}{l}\text { Servei de Neurologia- } \\
\text { Neuroimmunologia, Centre } \\
\text { d'Esclerosi Múltiple de } \\
\text { Catalunya (Cemcat), Institut } \\
\text { de Recerca Vall d'Hebron } \\
\text { (VHIR), Hospital Universitari } \\
\text { Vall d'Hebron, Universitat } \\
\text { Autònoma de Barcelona, } \\
\text { Spain }\end{array}$ & $\begin{array}{l}\text { Designed and } \\
\text { conceptualized the study; } \\
\text { acquisition and analysis } \\
\text { of the data; and drafted } \\
\text { the manuscript for } \\
\text { intellectual content }\end{array}$ \\
\hline
\end{tabular}

Appendix (continued)

\begin{tabular}{|c|c|c|}
\hline Name & Location & Contribution \\
\hline $\begin{array}{l}\text { Beatrice } \\
\text { Pignolet, } \\
\text { PhD }\end{array}$ & $\begin{array}{l}\text { CRC-SEP Neurosciences } \\
\text { Centre Hospitalier } \\
\text { Universitaire Toulouse, } \\
\text { CPTP INSERM UMR } 1043 \\
\text { CNRS UMR } 5282 \text { et } \\
\text { Université de Toulouse III, } \\
\text { UPS, France }\end{array}$ & $\begin{array}{l}\text { Acquisition and analysis } \\
\text { of the data and revised } \\
\text { the manuscript for } \\
\text { intellectual content }\end{array}$ \\
\hline $\begin{array}{l}\text { Jordi Rio, } \\
\text { MD, PhD }\end{array}$ & $\begin{array}{l}\text { Servei de Neurologia- } \\
\text { Neuroimmunologia, Centre } \\
\text { d'Esclerosi Múltiple de } \\
\text { Catalunya (Cemcat), Hospital } \\
\text { Universitari Vall d'Hebron, } \\
\text { Universitat Autònoma de } \\
\text { Barcelona, Spain }\end{array}$ & $\begin{array}{l}\text { Analysis of the data and } \\
\text { revised the manuscript } \\
\text { for intellectual content }\end{array}$ \\
\hline $\begin{array}{l}\text { Patrick } \\
\text { Vermersch, } \\
\text { MD, PhD }\end{array}$ & $\begin{array}{l}\text { Univ. Lille, Inserm U1172, } \\
\text { CHU Lille, FHU Imminent, } \\
\text { France }\end{array}$ & $\begin{array}{l}\text { Acquisition of the data } \\
\text { and revised the } \\
\text { manuscript for } \\
\text { intellectual content }\end{array}$ \\
\hline $\begin{array}{l}\text { Aurélie } \\
\text { Ruet, MD, } \\
\text { PhD }\end{array}$ & $\begin{array}{l}\text { Université, Bordeaux, } \\
\text { France, CHU de Bordeaux, } \\
\text { INSERM-CHU CIC-P 0005, \& } \\
\text { Services de Neurologie, } \\
\text { France, and Neurocentre } \\
\text { Magendie, INSERM U1215 } \\
\text { Bordeaux, France }\end{array}$ & $\begin{array}{l}\text { Acquisition of the data } \\
\text { and revised the } \\
\text { manuscript for } \\
\text { intellectual content }\end{array}$ \\
\hline $\begin{array}{l}\text { Jerome } \\
\text { deSèze, MD, } \\
\text { PhD }\end{array}$ & $\begin{array}{l}\text { Department of Neurology, } \\
\text { Hôpital Civil, Strasbourg, } \\
\text { France }\end{array}$ & $\begin{array}{l}\text { Acquisition of the data } \\
\text { and revised the } \\
\text { manuscript for } \\
\text { intellectual content }\end{array}$ \\
\hline $\begin{array}{l}\text { Pierre } \\
\text { Labauge, } \\
\text { MD, PhD }\end{array}$ & $\begin{array}{l}\text { Department of Neurology, } \\
\text { CHU Montpellier, France }\end{array}$ & $\begin{array}{l}\text { Acquisition of the data } \\
\text { and revised the } \\
\text { manuscript for } \\
\text { intellectual content }\end{array}$ \\
\hline $\begin{array}{l}\text { Sandra } \\
\text { Vukusic, } \\
\text { MD, PhD }\end{array}$ & $\begin{array}{l}\text { Department of Neurology } \\
\text { CHU Lyon, Bron, France }\end{array}$ & $\begin{array}{l}\text { Acquisition of the data } \\
\text { and revised the } \\
\text { manuscript for } \\
\text { intellectual content }\end{array}$ \\
\hline $\begin{array}{l}\text { Caroline } \\
\text { Papeix, MD }\end{array}$ & $\begin{array}{l}\text { Department of neurology, } \\
\text { Hôpital de la Salpétrière, } \\
\text { Paris, France }\end{array}$ & $\begin{array}{l}\text { Acquisition of the data } \\
\text { and revised the } \\
\text { manuscript for } \\
\text { intellectual content }\end{array}$ \\
\hline
\end{tabular}


Appendix (continued)

\begin{tabular}{|c|c|c|}
\hline Name & Location & Contribution \\
\hline $\begin{array}{l}\text { Laurent } \\
\text { Martinez- } \\
\text { Almoyna, } \\
\text { MD }\end{array}$ & Chi Aix en Provence, France & $\begin{array}{l}\text { Acquisition of the data } \\
\text { and revised the } \\
\text { manuscript for } \\
\text { intellectual content }\end{array}$ \\
\hline $\begin{array}{l}\text { Ayman } \\
\text { Tourbah, } \\
\text { MD, PhD }\end{array}$ & $\begin{array}{l}\text { Department of Neurology } \\
\text { and Faculté de Médecine de } \\
\text { Reims, CHU de Reims, } \\
\text { URCA, France; LPN EA2027 } \\
\text { Université Paris VIII, Saint- } \\
\text { Denis, Paris, France }\end{array}$ & $\begin{array}{l}\text { Acquisition of the data } \\
\text { and revised the } \\
\text { manuscript for } \\
\text { intellectual content }\end{array}$ \\
\hline $\begin{array}{l}\text { Pierre } \\
\text { Clavelou, } \\
\text { MD, PhD }\end{array}$ & $\begin{array}{l}\text { Department of Neurology, } \\
\text { CHRU Clermont Ferrand, } \\
\text { France }\end{array}$ & $\begin{array}{l}\text { Acquisition of the data } \\
\text { and revised the } \\
\text { manuscript for } \\
\text { intellectual content }\end{array}$ \\
\hline $\begin{array}{l}\text { Thibault } \\
\text { Moreau, MD, } \\
\text { PhD }\end{array}$ & $\begin{array}{l}\text { Department of Neurology, } \\
\text { CHU Dijon, France }\end{array}$ & $\begin{array}{l}\text { Acquisition of the data } \\
\text { and revised the } \\
\text { manuscript for } \\
\text { intellectual content }\end{array}$ \\
\hline $\begin{array}{l}\text { Jean } \\
\text { Pelletier, } \\
\text { MD, PhD }\end{array}$ & $\begin{array}{l}\text { Aix-Marseille Univ, APHM, } \\
\text { Hôpital de la Timone, Pôle } \\
\text { de Neurosciences Cliniques, } \\
\text { Service de Neurologie, } \\
\text { CNRS, CRMBM UMR 7339, } \\
\text { Marseille, France }\end{array}$ & $\begin{array}{l}\text { Acquisition of the data } \\
\text { and revised the } \\
\text { manuscript for } \\
\text { intellectual content }\end{array}$ \\
\hline $\begin{array}{l}\text { Christine } \\
\text { Lebrun- } \\
\text { Frenay, MD, } \\
\text { PhD }\end{array}$ & $\begin{array}{l}\text { Service de Neurology, CHU } \\
\text { de Nice Pasteur2, Université } \\
\text { Nice Cote d'Azur UR2CA } \\
\text { URRIS, France }\end{array}$ & $\begin{array}{l}\text { Acquisition of the data } \\
\text { and revised the } \\
\text { manuscript for } \\
\text { intellectual content }\end{array}$ \\
\hline $\begin{array}{l}\text { Bertrand } \\
\text { Bourre, MD }\end{array}$ & $\begin{array}{l}\text { Neurologie, CHU Rouen, } \\
\text { France }\end{array}$ & $\begin{array}{l}\text { Acquisition of the data } \\
\text { and revised the } \\
\text { manuscript for } \\
\text { intellectual content }\end{array}$ \\
\hline $\begin{array}{l}\text { Gilles Defer, } \\
\text { MD, PhD }\end{array}$ & $\begin{array}{l}\text { Neurologie, CHU Caen, } \\
\text { France }\end{array}$ & $\begin{array}{l}\text { Acquisition of the data } \\
\text { and revised the } \\
\text { manuscript for } \\
\text { intellectual content }\end{array}$ \\
\hline $\begin{array}{l}\text { Xavier } \\
\text { Montalban, } \\
\text { MD }\end{array}$ & $\begin{array}{l}\text { Servei de Neurologia- } \\
\text { Neuroimmunologia, Centre } \\
\text { d'Esclerosi Múltiple de } \\
\text { Catalunya (Cemcat), } \\
\text { Hospital Universitari Vall } \\
\text { d'Hebron, Universitat } \\
\text { Autònoma de Barcelona, } \\
\text { Spain }\end{array}$ & $\begin{array}{l}\text { Revised the manuscript } \\
\text { for intellectual content }\end{array}$ \\
\hline
\end{tabular}

Appendix (continued)

\begin{tabular}{|c|c|c|}
\hline Name & Location & Contribution \\
\hline $\begin{array}{l}\text { David } \\
\text { Brassat, MD, } \\
\text { PhD }\end{array}$ & $\begin{array}{l}\text { CRC-SEP Neurosciences } \\
\text { Centre Hospitalier } \\
\text { Universitaire Toulouse, } \\
\text { CPTP INSERM UMR } 1043 \\
\text { CNRS UMR } 5282 \text { et } \\
\text { Université de Toulouse III, } \\
\text { UPS, France }\end{array}$ & $\begin{array}{l}\text { Acquisition of the data } \\
\text { and revised the } \\
\text { manuscript for } \\
\text { intellectual content }\end{array}$ \\
\hline $\begin{array}{l}\text { Manuel } \\
\text { Comabella, } \\
\text { MD, PhD }\end{array}$ & $\begin{array}{l}\text { Servei de Neurologia- } \\
\text { Neuroimmunologia, Centre } \\
\text { d'Esclerosi Múltiple de } \\
\text { Catalunya (Cemcat), Institut } \\
\text { de Recerca Vall d'Hebron } \\
\text { (VHIR). Hospital Universitari } \\
\text { Vall d'Hebron, Universitat } \\
\text { Autònoma de Barcelona, } \\
\text { Spain }\end{array}$ & $\begin{array}{l}\text { Designed and } \\
\text { conceptualized the study; } \\
\text { analyzed the data; and } \\
\text { drafted the manuscript } \\
\text { for intellectual content }\end{array}$ \\
\hline
\end{tabular}

\section{References}

1. Polman $\mathrm{CH}, \mathrm{O}$ 'Connor PW, Havrdova E, et al. A randomized, placebo-controlled trial of natalizumab for relapsing multiple sclerosis. N Engl J Med 2006;354(9):899-910.

2. Bloomgren G, Richman S, Hotermans C, et al. Risk of natalizumab-associated progressive multifocal leukoencephalopathy. N Engl J Med 2012;366(20):1870-1880.

3. Kappos L, Bates D, Edan G, et al. Natalizumab treatment for multiple sclerosis: updated recommendations for patient selection and monitoring. Lancet Neurol 2011 10:745-758.

4. Khalil M, Teunissen CE, Otto M, et al. Neurofilaments as biomarkers in neurological disorders. Nat Rev Neurol 2018;14(8):577-589.

5. Kapoor R, Smith KE, Allegretta M, et al. Serum neurofilament light as a biomarker in progressive multiple sclerosis. Neurology 2020;95(10):436-444.

6. Dalla Costa G, Martinelli V, Moiola L, et al. Serum neurofilaments increase at progressive multifocal leukoencephalopathy onset in natalizumab-treated multiple sclerosis patients. Ann Neurol 2019;85(4):606-610.

7. Outteryck $\mathrm{O}$, Ongagna JC, Brochet $\mathrm{B}$, et al. A prospective observational post marketing study of natalizumab-treated multiple sclerosis patients: clinical, radiological and biological features and adverse events. The BIONAT cohort. Eur J Neurol 2014;21(1):40-48.

8. Schwab N, Schneider-Hohendorf T, Posevitz V, et al. L-selectin is a possible biomarker for individual PML risk in natalizumab-treated MS patients. Neurology 2013; 81(10):865-871.

9. Pignolet B, Schwab N, Schneider-Hohendorf T, et al. CD62L test at 2 years of Natalizumab predicts progressive multifocal leukoencephalopathy. Neurology 2016; 87(20):2491-2494.

10. Fissolo N, Pignolet B, Matute-Blanch C, et al. Matrix metalloproteinase 9 is decreased in natalizumab-treated multiple sclerosis patients at risk for progressive multifocal leukoencephalopathy. Ann Neurol 2017;82(2):186-195.

11. Kuhle J, Barro C, Andreasson U, et al. Comparison of three analytical platforms for quantification of the neurofilament light chain in blood samples: ELISA, electrochemiluminescence immunoassay and Simoa. Clin Chem Lab Med 2016;54(10) 1655-1661. 


\title{
Neurology \\ Neuroimmunology \& Neuroinflammation
}

\author{
Serum Neurofilament Levels and PML Risk in Patients With Multiple Sclerosis \\ Treated With Natalizumab \\ Nicolás Fissolo, Beatrice Pignolet, Jordi Rio, et al. \\ Neurol Neuroimmunol Neuroinflamm 2021;8; \\ DOI 10.1212/NXI.0000000000001003
}

This information is current as of April 26, 2021

\section{Updated Information \& Services}

References

Citations

Subspecialty Collections

Permissions \& Licensing

Reprints including high resolution figures, can be found at:

http://nn.neurology.org/content/8/4/e1003.full.html

This article cites 11 articles, 0 of which you can access for free at: http://nn.neurology.org/content/8/4/e1003.full.html\#\#ref-list-1

This article has been cited by 2 HighWire-hosted articles: http://nn.neurology.org/content/8/4/e1003.full.html\#\#otherarticles

This article, along with others on similar topics, appears in the following collection(s):

Class I

http://nn.neurology.org//cgi/collection/class_1

Multiple sclerosis

http://nn.neurology.org//cgi/collection/multiple_sclerosis

Information about reproducing this article in parts (figures,tables) or in its entirety can be found online at:

http://nn.neurology.org/misc/about.xhtml\#permissions

Information about ordering reprints can be found online:

http://nn.neurology.org/misc/addir.xhtml\#reprintsus

Neurol Neuroimmunol Neuroinflamm is an official journal of the American Academy of Neurology.

Published since April 2014, it is an open-access, online-only, continuous publication journal. Copyright

Copyright (C) 2021 The Author(s). Published by Wolters Kluwer Health, Inc. on behalf of the American

Academy of Neurology.. All rights reserved. Online ISSN: 2332-7812.

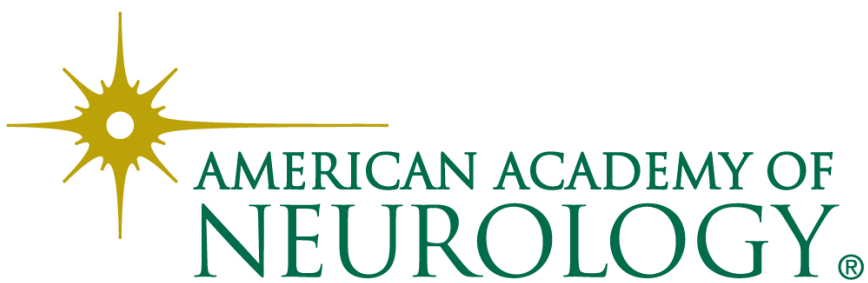

